\title{
CHANGE MANAGEMENT IN LEAN ENTERPRISE
}

\author{
JoANNA FURMAN, MARZENA KUCZYŃSKA-CHAŁADA
}

\begin{abstract}
A B S TR A C T
The main purpose of the paper is the analysis of a process of change focusing particularly on the concept of slimmed production (Lean) and its implementation in the enterprise. A case study method was chosen as a research tool because it offers wide array of techniques and means of gaining and analysing data.

A metallurgical company was evaluated as a case study in this article. Thanks to the implementation of Autonomous Maintenance the company reached a growth in skills and responsibility for work done and a reduction in malfunction at work places. Thus, total process maintenance (TPM) as one of the Lean concept tools whose implementation significantly influences industrial workers' competences was chosen for the analysis. Referring to the bibliography on change management, the article focused on one of the changes in particular - the change in human resources management (namely in employees' skills) in steel and manufacturing companies.
\end{abstract}

KEY WORDS

change management, Lean Manufacturing concept, autonomous maintenance, employee involvement

DOI: 10.1515/emj-2016-0013
Corresponding authors:

Joanna Furman Silesian University of Technology,

Poland

e-mail:

joanna.furman@polsl.pl

Marzena Kuczyńska-Chałada Silesian University of Technology, Poland

e-mail: marzena.kuczynska-chalada@polsl.pl

\section{INTRODUCTION}

Changes occurring in the environment as well as clients' growing requirements have led to increased interest in new methods and concepts of enterprise management. Enterprises introduce changes through the use of methods, techniques and tools adequate for their business activity and needs. It is essential to outline the importance of Lean Manufacturing (LM) concept which is common in many production enterprises. LM - created in 1950s in the Toyota company - assumes limiting both certain functions implemented by the enterprise and its resources. As a result of its implementation, enterprises achieve higher productivity, boost performance and quality of produced goods and provided services and - most of all - become client-oriented in every action they take. The concept involves putting an emphasis on teamwork, increasing the autonomy of employees, taking care of their development, striving to constantly improve the organisation of work and elimination of mistakes (Gajdzik et al., 2011). The Lean concept is introduced in the enterprise through the use of tools such as the 5S method, kaizen, SMED or TPM. Change management in this case refers to an entirely different management of processes, where a significant role is played by the human factor, i.e. the employees of the enterprise. Without their involvement and cooperation it is impossible to achieve the desired results of the implementation of the concept.

This paper illustrates the gist of change management in organisations, putting a particular emphasis on lean production and its implementation 
in the enterprise. One category of changes was focused on changes in the manner of employee management (i.e. within the scope of their skills).
Therefore, one of the Lean concept tools was selected for analysis - total productive maintenance (TPM), the implementation of which significantly influences

Tab. 1. Changes - basic notions and change features

\begin{tabular}{|c|c|c|}
\hline SOURCE & ChANGE DEFINITION & Change features \\
\hline Griffin R. W. & $\begin{array}{l}\text { - „a change is every significant } \\
\text { modification of some part of the } \\
\text { enterprise", } \\
\text { - } \text { a change concerns many } \\
\text { aspects of the functioning of the } \\
\text { enterprise and its environment, } \\
\text { - "a change in the enterprise can } \\
\text { lead to results falling outside the } \\
\text { area of change" }\end{array}$ & $\begin{array}{l}\text { - change caused in the enterprise changes } \\
\text { that enterprise, } \\
\text { - change has unlimited scope, } \\
\text { - a change influences other aspects of } \\
\text { human life and existence, } \\
\text { - a change is unpredictable, we cannot } \\
\text { define the scope of influence of the } \\
\text { introduced change }\end{array}$ \\
\hline Stoner J. A. F. & $\begin{array}{l}\text { - },(. . .) \text { a planned change is } \\
\text { systematic strive to redesign } \\
\text { the enterprise in such a way so } \\
\text { as to facilitate its adjustment } \\
\text { to dramatic changes in the } \\
\text { environment and to achieve new } \\
\text { goals" }\end{array}$ & $\begin{array}{l}\text { - } \quad \text { change can be planned, } \\
\text { - change introduction requires systematic } \\
\text { action, } \\
-\quad \text { change changes the enterprise, } \\
-\quad \text { change is a chance for the enterprise itself } \\
\text { - } \text { in enterprise must adjust to the changes } \\
\text { round, } \\
-\quad \text { changes have radical nature, } \\
-\quad \text { changes are unavoidable, } \\
-\quad \text { changes in the surrounding are dynamic, } \\
-\quad \text { change is a new challenge for the } \\
\text { enterprise }\end{array}$ \\
\hline Clarke L. & $\begin{array}{l}\text { - "change has to be treated as } \\
\text { something inevitable and it } \\
\text { should not be opposed" }\end{array}$ & $\begin{array}{l}\text { - one must subject oneself to change, } \\
\text { - change is unavoidable in turbulent } \\
\text { surrounding }\end{array}$ \\
\hline Drucker P. F. & $\begin{array}{l}\text { - „in turbulent times managers } \\
\text { cannot assume that tomorrow } \\
\text { will be the same as today” }\end{array}$ & $\begin{array}{l}\text { - change dynamics, } \\
\text { - } \text { no stability in the contemporary world }\end{array}$ \\
\hline $\begin{array}{l}\text { Carr D. K., Hard K. J. } \\
\text { Trahant W. J. }\end{array}$ & $\begin{array}{l}\text { - changes have become the only } \\
\text { certain aspect of the modern } \\
\text { business }\end{array}$ & $\begin{array}{l}\text { - changes are irreversible, } \\
\text { - changes must be monitored, } \\
\text { - } \text { the change process cannot be stopped, } \\
\text { - } \quad \text { no stability in the global economy }\end{array}$ \\
\hline Handy Ch. & $\begin{array}{l}\text { - } \text { "(...) changes today are not } \\
\text { what they used to be yesterday. } \\
\text { Nowadays, maintaining the } \\
\text { current status quo is not the best } \\
\text { way to plan the future" }\end{array}$ & $\begin{array}{l}\text { - changes are unavoidable, } \\
\text { - changes are dynamic }\end{array}$ \\
\hline Zarębska A. & $\begin{array}{l}\text { - a change is the ability to meet } \\
\text { the requirements set by the } \\
\text { competition - otherwise, the } \\
\text { enterprise may fall }\end{array}$ & $\begin{array}{l}\text { - a change cannot be merely adapting in its } \\
\text { character, it also has to be anticipatory - } \\
\text { the enterprise should be ahead of changes, } \\
\text { - a change itself is nothing new for the } \\
\text { human, it is the rate at which it is } \\
\text { introduced that is very fast. }\end{array}$ \\
\hline Nizard G. & $\begin{array}{l}\text { - „a change is a process, a } \\
\text { statement of difference between } \\
\text { one state and another, without } \\
\text { indicating its causes, forms or } \\
\text { effects" }\end{array}$ & $\begin{array}{l}\text { - } \text { process approach to change, } \\
\text { - } \text { change result, new thing, form, new person }\end{array}$ \\
\hline
\end{tabular}

Source: (Griffin, 2000, p. 393; Stoner, 1998, p. 306; Clarke, 1997, p. 7; Drucker, 1993, p. 47; Carr et al., 1998, p. 9; Handy, 1996, p. 45; Zarębska, 2002, p. 19; Nizard, 1998, p. 107). 
the competences of production employees (within the pillar of Autonomous Maintenance). The process of change was presented on the basis of a metallurgical enterprise.

\section{ESSENCE OF CHANGE MANAGEMENT}

Change management is a part of the science of enterprise management. The issue was developed on the basis of the practice and as a result of dynamic environment. That changes occur in the environment where the organisation has to have a certain action policy is a fact. An indication for change introduction is both the environment and enterprise itself - each area in the enterprise can generate changes (Tab. 1).

Nowadays, change management is an indispensable skill for managers. Their understanding of the essence of change in the enterprise is what its market success depends on. Changes introduced in the organisation are a result of many various forces. The external and internal factors stimulate change in the enterprise. It can be divided into four categories (Griffin, 2000):
- in the strategy of the enterprise (changes within strategic goals, strategic unit portfolio and functional strategies; mergers; joint ventures and internationalisation);

- in the structure and projects of the enterprise (redesign of work stations, structuralisation, changes in formal authority distribution, modernisation in the coordination mechanism, etc.);

- in technology and operations (new equipment, changes in working processes and working sequences, implementation of IT systems and control systems);

- in the manner of management of employees (changes in the scope of skills, performance, feelings, attitudes and values assumed by the employees in the enterprise).

The types of change shown in table 1 do not exhaust the possible classification. There are multiple approaches to the change classification. Different authors also have different approach to the process of change in the environment. A range of models of change introduction in the organisation have been developed through years. One of the first was the model developed by K. Lewin (1947) presented in figure 1.

Tab. 2. Types of changes in the enterprise

\begin{tabular}{|c|c|}
\hline DIVISION CRITERION & ChANGE TYPES \\
\hline Change degree & $\begin{array}{l}\text { - } \quad \text { reproductive (refer to the organisational level of the enterprise), } \\
\text { - } \quad \text { transformational (refer to the strategical level of the enterprise) }\end{array}$ \\
\hline Repair impulse nature & $\begin{array}{l}\text { - voluntary (the organisation itself sees the need for change), } \\
\text { - } \quad \text { compulsory (a reaction to a critical situation in the enterprise) }\end{array}$ \\
\hline $\begin{array}{l}\text { Relationship of organisational change } \\
\text { time with change in the environment }\end{array}$ & $\begin{array}{l}\text { - reactive (reaction of the enterprise to changes in the environment), } \\
\text { - } \text { anticipatory (the enterprise anticipates changes in the environment } \\
\text { and prepares for them) }\end{array}$ \\
\hline Change nature & $\begin{array}{l}\text { - } \text { adaptive (the adaptation of the enterprise to new conditions), } \\
\text { - innovative (the organisation introduces new solutions and new } \\
\text { products and often for the first time, as an experiment) }\end{array}$ \\
\hline Change scope & $\begin{array}{l}\text { - } \quad \text { fractional (regards a fragment of the enterprise), } \\
\text { - comprehensive (covers the entire enterprise) }\end{array}$ \\
\hline Change subject & 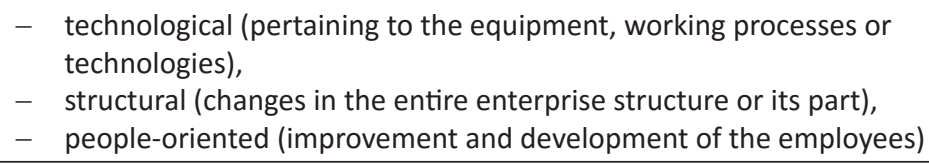 \\
\hline Change implementation method & $\begin{array}{l}\text { - } \text { evolutionary (gradual, in small steps), } \\
\text { - } \quad \text { revolutionary (violent) }\end{array}$ \\
\hline Change process continuity & $\begin{array}{l}\text { - } \text { gradual (constant introduction of slight changes in the enterprise } \\
\text { according to new circumstances), } \\
\text { - in leaps (abrupt changes, usually irreversible) }\end{array}$ \\
\hline
\end{tabular}

Source: (Majchrzak, 2002, p. 15). 


\section{DEFROSTING}

Fig. 1. Change management model in organisation acc. to K. Lewin

Source: (Lewin, 1947, p. 12).

The first step is the defrosting, i.e. the preparation of people and the enterprise for a change, the second step is the change itself and the third one - frosting, i.e. the consolidation of the change in the system, which is the enterprise itself.

A key part in the process of introducing changes in the enterprise is the so-called force field analysis, the essence of which is the confrontation of two opposite forces: facilitating and inhibiting the achievement of the set goal (Fig. 2). (internal and external factors). Overcoming resistance towards the change is also very sagnificant and can be done through frequent communication with the employees, removal of change blocking barriers, rewarding of positive attitudes of employees towards the changes, trainings, encouraging employees to cooperate in introduction of changes in the enterprise (Gajdzik, 2007). These problems can be encountered when implementing new methods and conceptions. One of them is Lean Manufacturing.

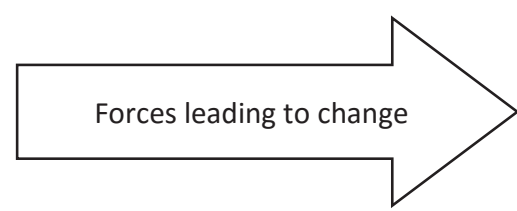

Change subject

(change essence)

Forces not leading to change

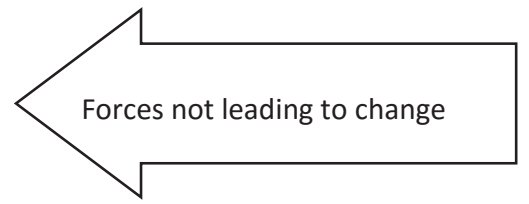

Fig. 2. Force field in the change management process Source: (Griffin, 2000, p. 401).

According to Z. Mikołajczyk (2003), the process of changes in the enterprise and its consecutive stages are:

- diagnosis phase, covering determination and definition of the problem through diagnosis,

- search phase - proposals of various solution variants,

- decision phase, i.e. evaluation of solutions according to the assumed criteria (selection of an optimal solution), enterprise design, introduction of changes through author supervision,

- evaluation phase - assessment of effects of the change introduced in the enterprise.

Enterprise employing change planning uses, inter alia, the Copper and Lybrand's model (Carr et al., 1998), the basic stages of which are: estimation (analysis of the current situation, definition of the goal and nature of changes), change planning, implementation and renewal. Success of the introduced change is a sum of several components, i.e.: vision, need, means, rewards and team evaluation.

The changes introduced in the enterprise must be planned, they implementation must follow adopted procedures (evaluation, plan, implementation, renewal), and the enterprise must take into account multiple factors in this process, necessary for success

\section{LEAN MANUFACTURING CONCEPTION}

Lean manufacturing means making production less demanding in terms of necessary material resources, kept ready product stocks and production in progress as well as used area of production floors. It is a conception of enterprise improvement which, through continuous elimination of various forms of wastage, optimises creation and flow of value in the manufacturing process. There can be 7 categories of wastage distinguished: over-production, standstills, failures, redundant operations, improper processing, excessive stocks, redundant internal transport. This list includes also failure to use employees' creativity, as they can be a source of ideas regarding process improvement which contributes to a great extent to elimination of wastage (Furman \& Burchart-Korol, 2008).

All employees take part in Lean Manufacturing actions including the company executive director and machines operators. With the help of trainers special teams are created, who analyze current wastage, plan its reduction and implement already planned actions. 
By engaging more and more people in team-work activities and providing time for problems solving, the company undergoes transformation of its working culture and succeeds in implementing Lean Manufacturing idea.

The aim of Lean Manufacturing is to create simple and clear structures within a company and enlarge the importance of human resources in order to use them in the best way possible. The factor responsible for winding up the spiral of continuous development is five rules (Antosz, 2015):

- accurately define value of a certain product,

- identify the values stream for each product,

- guarantee untroubled flow of values,

- implement sucking system, drive to be perfect.

Enterprises introducing changes through implementation of the Lean conception must choose a proper LM tool, so that its use brings the expected results. The basic Lean Manufacturing tools include, inter alia: value stream mapping, 5S method connected with work station organisation, Kaizen continuous improvement method, reduction of engagement time based on the SMED method, maintenance management based on TPM. All these tools require engagement of employees and introduction of changes in their behaviors and daily work. AN example of change in the employee management method - within the scope of their skills - is the TPM conception.

\section{TPM CONCEPTION AND AUTONOMOUS MAINTENANCE AS A CHANGE EXAMPLE IN COMPETENCE WORKERS}

Total Productive Maintenance is defined as a continuous process of servicing machinery and equipment implemented within the entire enterprise by all operators and maintenance technicians. TPM focuses on maximizing the efficiency of the machinery by applying actions to prevent accidents during the whole period of use. Thanks to implementation of TPM every machine in the manufacturing process is capable to do tasks, as there are no disruptions in the production process (Furman \& Małysa, 2015). TPM is a tool that helps to detect and reduce waste by means of three zeroes: zero breakdowns, zero defects, zero accidents at work. TPM program include actions in these five main areas (Gajdzik, 2009):

- educating all employees starting from top management positions to production line workers in order to change their awareness concerning everything that constitutes an effective manufacturing system,

- creating a system which all implementation actions would be based on teamwork,

- starting from the introduction of $5 S$ method i.e. introducing order through the removal of unnecessary things, thorough cleaning and visualizing the process of management,

- creating a system of impartial assessment and comparison of results for the individual workplaces,

- developing and implementing the continuous workers' awareness management in the health and safety systems.

TPM theory is built on seven pillars, where the most important is Autonomous Maintenance. These are activities which purpose is to enable workers to service machines by themselves, regardless of the maintenance department, e.g. detect anomalies, simple repairs, control precision. In the production plants with the traditional division of responsibilities, there is a belief that the maintenance department, is solely responsible for the maintenance of machinery and equipment even for the small incidents. Therefore, engaging operators in simple maintenance tasks of Autonomous Maintenance can offload the maintenance personnel and, above all, contribute to the progressive elimination of failure at the workplace. The main objectives of AM include, among others:

- identifying and eliminating the causes of variability of performance,

- striving to improve performance,

- increase of operators participation in the maintenance of machines which they operate, and thus development of their skills,

- increase of operators responsibility for the technical condition of the machines,

- integration of the production and maintenance,

- improving the quality of workplace.

The implementation of Autonomous Maintenance is carried out in seven steps, allowing workers to develop the right skills and what is expected of them (Fig. 3). The first five steps involve the so-called hard mechanical aspects of machine maintenance. These are activities which maintain suitable state of machines and prevent excessive wear and their activities related to the development of standards for cleaning, lubrication, tightening the fasteners, controls. Step six focuses on aspects related to organizing, standardization and visual management of machines maintenance. The last step is to conduct 


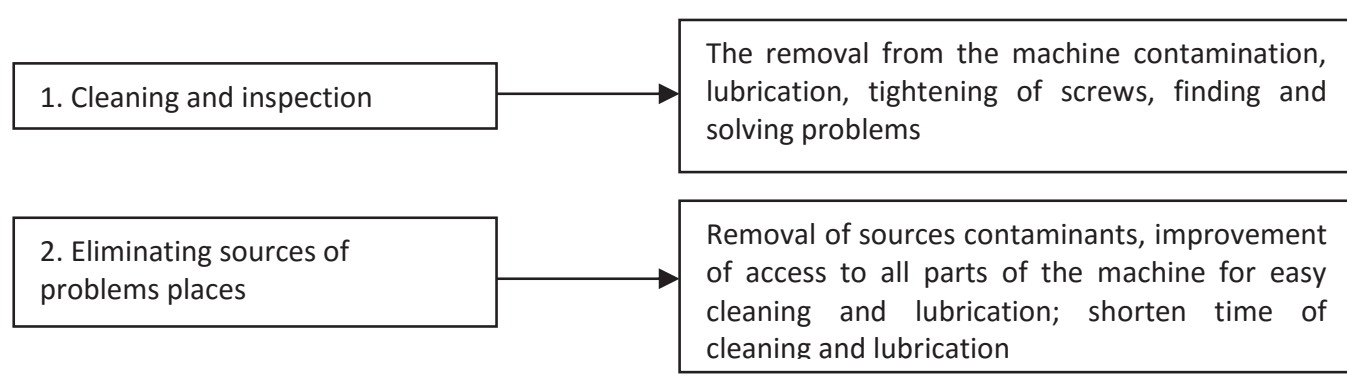

3. Designation of cleaning and lubrication standards

Setting up operational standards for the effective conduct of the cleaning, lubrication, tightening the screws (draw up a work schedule of periodic)

4. Carrying out a general inspection of machine
Training based on the manual equipment, to carry out a general inspection of machines in order to detect and eliminate small irregularities

Developing checklists for autonomous inspection; perform the inspection
5. Carrying out an autonomous inspection of machine

6. Introduction of visual equipment maintenance of management
Standardization and visual management of all activities associated with the maintenance of the machines. Developing a general system for maintenance management of machinery. Standards needed: cleaning, lubrication and inspection; flow of materials; data collection; management of tools
7. Introduction of a permanent autonomous management
Developing principles and objectives of the enterprise; introduction of improvement activities in their daily work; collecting data on the average time between failures, analysis and use of data to improve machine park
Fig. 3. Phases of Autonomous Maintenance

Source: study based on (The Productivity ..., 2012, p. 65).

independent operations by workers (Productivity Developement Team, 2012).

During the implementation of the Autonomous Maintenance, the important role play the following factors (Kruczek \& Żebrucki, 2012):

- employees expertise in safety conditions existing at the workplace,

- understanding of the principles of machines through the instructions and organized one-point lessons,

- knowledge and ability to identify the symptoms informing about the improper operation of the machines, the ability to respond and take corrective measures,
- ability of operators to perform maintenance activities.

- The important role of maintenance services in the communication and increasing knowledge and skills of operators, especially in the first four steps of the implementation of the Autonomous Maintenance should be emphasized - without their involvement and support it is not possible to acquire full autonomy by operators. 


\section{IMPLEMENTATION OF AUTONOMOUS MAINTENANCE RULES IN THE METALLURGICAL ENTERPRISE}

In order to improve effective maintenance, the metallurgical enterprise has introduced Autonomous maintenance to develop operators' skills and engage them more in machine operation.

Stages of implementation of the TPM include: designation of areas of implementation and specifying the schedule of activities, training employees, developing a structure for the TPM system through the appointment of teams and their leaders responsible for implementation in specific area of the plant, the choice of pilot area with the determination of production machines, evaluation of effectiveness of actions.

Based on the assumptions of TPM the metallurgical enterprise has introduced the four pillars of improvement of the manufacturing process:

- Focused Improvement - assumption of work within the framework of multi-functional work teams. Specified operations are performed according to the work schedule to ensure the reliability of the machines. Operators take care of the machines, look for the ways to improve their efficiency;

- Autonomous Maintenance - inclusion of operators in comprehensive service of machines;

- Professional Maintenance - the essence is mainly to eliminate the breakdowns of machines by actions which improve the reliability of elements of metallurgical machines. Actions which are conducted are preventive repairs which are performed by specialized teams of workers;

- Early Equipment Maintenance - is associated with the construction of a system to ensure the design, purchase, production of equipment easy to operate and maintain.

In the implementation of TPM system in every industrial enterprise attention is drawn to the aspect of engagement and staff awareness, especially at the operational level. The pillar of Autonomous Maintenance, which was implemented in the enterprise, contributed to the increase of employees liability to operated machines and to the reduction of number of failures at the workplace. Operators within the AM are required to assess the efficiency of their work station before starting work, for maintenance of cleanliness and for the removal any dirt. In addition, operators are required to maintain normal operating conditions of machines and equipment and restore the initial conditions of operation. Operators inspecting machines and equipment are able to detect and eliminate irregularities related to their work. Irregularities are subjected to identification by each employee who is required to complete the appropriate label. Labels are available in two colours: blue - when the employee repairs by himself or with the participation of technical service workers and red when irregularities are repaired by workers of Professional Maintenance). Labels are used for classification of machinery and equipment into categories. Each production plant determines which machines are the most critical - that is, those whose failures result in complete stop or slowdown of production (referred to as Category AA). Other categories of machines are designated as $\mathrm{A}, \mathrm{B}$ or $\mathrm{C}$ (Gajdzik, 2014).

An element aimed at increasing the efficiency of operating activities among operators was also the development of the competence matrix which is a set of key skills of the employees from the enterprise's point of view. The matrix covers and determines the scale of knowledge and skills that the operators must possess. The starting point in creation of the matrix in the enterprise was determination of the most important operator skills. At this stage, the following question was posed: „what knowledge and skills must an employee have, so that the tasks of autonomous maintenance can be performed?" developing Afterwards, the descriptions of particular competences were defined first and then the marking scale was established (from 1 - beginner employee, to 4 - experienced employee).

The skills of the operators were evaluated in relation to the tasks required for performance at the work station. Analysing the current level of employee competences, the enterprise gains knowledge on the actions the operator must undertake to perform these activities (e.g. skill improvement trainings).

In order to increase the efficiency of the machinery, operators deepen technological knowledge on the functioning of the machines and gain new skills during the training. In addition, meetings of teams working with the use of „Brainstorming” are organized to solve problems and prepare action plans providing solution to the problem on the production level. Thanks to the knowledge and skills acquired by the operators in the metallurgical enterprise, process improvement is observed as a result of the implementation of employees ideas. It effects in 
reduced costs, repairs, less frequent replacement of parts, quick response to problems and cleanliness of work stations. Tables should be prepared according to the example (Tab. 1).

\section{CONCLUSIONS}

Introduction of new management methods and concepts is a response to the changing surrounding and increasing expectations of customers. Enterprises which fail to react to these signals cannot face the competition. Introduction of the Lean Manufacturing concept in the analysed enterprise (through TPM introduction) has contributed, first and foremost, to a decreased failure rate of the operated machines (main goal of changes) as well as an increase in skills and responsibility for the performed work. The Autonomous Maintenance implementation process required engagement of the entire team as well as changes in behavior and everyday habits. Introduction of changes in the enterprise was not an easy or fast process, but it provided the expected results.

\section{LITERATURE}

Antosz, K., Pacana, A., Stadnicka, D., \& Zielecki, W. (2015). Lean Manufacturing. Doskonalenie produkcji, [Lean Manufacturing. Improving production]. Rzeszów, Poland: Wydawnictwo Politechniki Rzeszowskiej.

Carr, D. K., Hard, K. J., \& Trahant, W. J. (1998). Zarządzanie procesem zmian [Management the change process]. Warszawa, Poland: Wydawnictwo Naukowe PWN.

Clarke, L. (1997). Zarzadzanie zmiang [Change management]. Warszawa, Poland: Gebethner\& Ska.

Drucker, P. F. (1993). Zarządzanie w czasach burzliwych [Management in turbulent times]. Kraków, Poland: Wydawnictwo Akademii Ekonomicznej.

Furman, J., \& Burchart-Korol, B. (2008). Wprowadzenie do problematyki wdrażania Lean Manufacturing w odniesieniu do przedsiębiorstw hutniczych [Introduction to implementing Lean Manufacturing in relation to steel company]. Hutnik, 75(3),120-125.

Furman, J., \& Małysa, T. (2015). The safe usage of machinery in the aspect of Autonomous Maintenace in the steel company. Hutnik, 82(7), 453-456.

Gajdzik, B. (2007). Uczenie się - podstawa rozwoju przedsiębiorstwa [Learning - the basis for enterprise development]. Problemy Jakości, 39(3), 37-40.

Gajdzik, B. (2009). Introduction of Total Production Maintenance in steelworks plants. Metalurgija, 48(2), 137-140.
Gajdzik, B. (2014). Autonomous and Proffesional Maintenance in metallurgical enterprise as activities within Total Productive Maintenance. Metalurgija, $53,269-272$.

Gajdzik, B., Kuczyńska-Chałada, M., \& Sosnowski, R. (2011). Organizacja $i$ zarządzanie $w$ przemyśle [Organization and management in industry]. Gliwice, Poland: Wydawnictwo Politechniki Śląskiej.

Griffin, R. W. (2000). Podstawy zarządzania organizacjami [Basics of organizations management]. Warszawa, Poland: Wydawnictwo Naukowe PWN.

Handy, Ch. (1996). Wiek paradoksu. W poszukiwaniu sensu przyszłości [Age of paradox. In the search for meaning of future]. Warszawa, Poland: Dom Wydawniczy ABC.

Kruczek, M., \& Żebrucki, Z. (2012). Doskonalenie procesów utrzymania ruchu $\mathrm{w}$ przedsiębiorstwie branży hutniczej [Improvement of the maintenance processes in the enterprise of metallurgical industry]. Logistyka, supp. Logistyka - nauka, 2.

Lewin, K. (1947). Frontiers in Group Dynamics, Concept Method and Reality in Social Science. Human Relations, 1(1), 5-41.

Majchrzak, J. (2002). Zarządzanie zmianami $w$ przedsiębiorstwie [Change management in the enterprise]. Poznań, Poland: Wydawnictwo Akademii Ekonomicznej.

Mikołajczyk, Z. (2003). Zarządzanie procesem zmian $w$ organizacji [Management the change process in organizations]. Katowice, Poland: GWSH.

Nizard, G. (1998). Metamorfozy przedsiębiorstwa zarzadzanie $w$ zmienionym otoczeniu organizacji [Metamorphoses company - management in a changing environment of the organization]. Warszawa, Poland: Wydawnictwo Naukowe PWN.

Stoner, J. A. F. (1998). Kierowanie [Managing]. Warszawa, Poland: Wydawnictwo Naukowe PWN.

The Productivity Press Development Team (2012). TPM dla każdego operatora [TPM for each operator]. Wrocław, Poland: ProdPublishing.

Zarębska, A. (2002). Zmiany organizacyjne $w$ przedsiębiorstwie [Organisational changes in the company]. Warszawa, Poland: Difin. 